\title{
Financial Support Mechanisms and Financing Instruments for Climate Change Adaptation
}

\author{
Shih-Fang Lo ${ }^{*}$, Chou-Yen $\mathrm{Wu}^{2}$, Chun-Hsu Lin ${ }^{1}$ \\ ${ }^{1}$ Center for Green Economy, Chung-Hua Institution for Economic Research, Taiwan \\ ${ }^{2}$ Research Division V, Taiwan Institute of Economic Research, Taiwan \\ Email: "shihfang.lo@gmail.com, chouyen0312@gmail.com,chlin@cier.edu.tw
}

Received 5 June 2014; accepted 22 February 2016; published 25 February 2016

Copyright (C) 2016 by authors and Scientific Research Publishing Inc.

This work is licensed under the Creative Commons Attribution International License (CC BY). http://creativecommons.org/licenses/by/4.0/

(c) (i) 0pen Access

\section{Abstract}

Extreme weather has been having an increase in frequency and severity because of global warming. Heavy financial burden on governments has been increasing as reconstruction of natural disaster and prevention of public construction spending. Unlike the climate mitigation activities, the main purpose of climate adaptation is to establish climate risk management system. We discuss several types of financing instruments and collect several cases in both developed and developing countries internationally. We find that budget reallocation or government bonds are regularly used for losses from natural disaster in developing countries while both government bonds and insurance penetration are used to against catastrophe risks in the developed countries. Finally, we also find that insurance-related instruments are feasible and have been applied in some middleincome countries with assistance from the World Bank.

\section{Keywords}

Climate Change Adaptation, Insurance Tools, Capital Market, Review, Case Study

\section{Introduction}

The Adaptation Framework was set at COP16 held in Mexico in 2010. Climate adaptation aims to establish the climate risk management system, being different from climate mitigation. In addition to reviewing the present natural relief and insurance system, governments should consider to combine a robust function of climate change insurance and present government fiscal relief system to adapt the climate change damage to physical

*Corresponding author. 
and property when governments face an increase in climate risk in the future.

With the threat of global warming, frequency of climate-related extreme weather events dramatically increases. According to the statistics of Munich Re., number of events of weather catastrophes increases dramatically especially for hydrological events and climatological events after 2006. There were more than 950 natural disasters and 90\% of them were weather related in 2010, costing a total of at least \$130 billion. An increase in climate-related extreme weather events potentially manifest the fact that governments have to pay much attention to disaster risk management (Linnerooth-Bayer and Mechler, 2006) [1], especially for high losses from natural catastrophe and low insurance penetration for natural catastrophe in Asian countries.

Michel-Kerijan et al. (2011) [2] suggest four-level approach based on its priorities and level of economic development for governments. They introduce that both the insurance penetration and the level of technical expertise in risk management increase as the economic development of countries from Level 1 to Level 4 countries since people afford to pay insurance in Level 4 countries compared with in Level 1 countries. For example, financial coverage against natural disaster is often absent in Level 1 countries (i.e., low-income economies) thus the country relies on post-disaster funding from international donors. On the contrast, high insurance and reinsurance penetration against natural disaster and government supplements by allocating catastrophic risk capital in Level 4 countries (i.e., high-income economies). The risks are also generally covered by both public and private sector. This paper aims to investigate the ex-ante and post-disaster financial instruments for climate change adaptation according to the four-level approach provided by Michel-Kerijan et al. (2011) [2]. Ghesquiere and Mahul (2010) [3] suggest that different types of financing instruments have to be used in different phase after disaster. They pointed that the design of an efficient financial protection strategy must consider the time dimension because the financial instruments are synchronized with the capacity. Ghesquiere and Mahul (2010) [3] divide financing instruments into ex-ante financing and post-disaster financing instruments. Furthermore, phases are divided into relief phase ( 1 - 3 months after disasters), recovery phase (3 - 9 months after disasters), and reconstruction phase (more than 9 months after disasters). Thus, we introduce main financial instruments of climate change adaptation financial support mechanism and cases what financial instruments are used. We also apply both four-level approach in Michel-Kerijan et al. (2011) [2] and financial instruments suggested by Ghesquiere and Mahul (2010) [3] to discuss cases of financial instruments in this paper.

The rest of the paper is organized as follows. Section 2 presents the losses caused by natural disasters in the past. Section 3 introduces the climate change adaptation and economic theories. The financial instruments and cases are both shown in Section 4. Finally, Section 5 concludes.

\section{Losses from Natural Disasters}

Climate change leads to climatic anomaly. With the threat of global warming, frequency of climate-related extreme weather events dramatically increases, including typhoons, flood, extreme temperatures, drought, forest fires, and other weather hazards, in recent years. Large economic losses from natural disasters caused by climate changes have also become a heavy burden of the society and government. Governments must be responsibility for reconstructing the infrastructure. The principal aim for governments is that complete reconstruction using plenty of reconstruction funds but this also lead to the heavy burden on government finance.

According to the statistics of Munich Re., number of events of weather catastrophes increases dramatically especially for hydrological events and climatological events after 2006. Table 1 shows global natural disasters obtained from CRED EM-DAT database [4] from 1900 to 2013. It shows that meteorological disasters have led to the largest number of events (7149 events) and total losses ( $\$ 198.49$ billion) while climatological disasters have led to the largest death toll (11,881,372 people) and average losses per event (135,858 thousands). In Panel $B$, the largest number of events, death toll, total affected, total losses, and average losses per event were caused by drought. Droughts have resulted in 11,707,611 people died and in loss of $\$ 88.67$ billion. For meteorological disasters, tropical cyclones have resulted in a loss of $\$ 1304.80$ billion and 2,668,884 people died since 1900 . Tropical cyclone also results in the largest losses compared with other natural disasters (Panel D, Table 1).

In August, 2005, Hurricane Katrina caused deaths and flooding, and its damage was around \$125 billion with $\$ 62$ billion in insured losses. Cyclone Nargis swept across the Bay of Bengal and Myanmar, resulting in approximately 140,000 people died and destruction of infrastructure. Actually, according to the data provided by UNEP [5], the global natural disasters have resulted in loss of $\$ 62$ billion, and 15,000 people died worldwide in 2009. Moreover, a total of loss caused by extreme weather has risen in 2010 and more than twice as loss as 2009. 
Table 1. Global weather disasters from 1900 to the present.

\begin{tabular}{|c|c|c|c|c|c|}
\hline Disasters & \# of Events & Death toll & Total Affected & $\begin{array}{c}\text { Total losses } \\
\text { (US\$ thousands) }\end{array}$ & $\begin{array}{l}\text { Avg. losses per event } \\
\text { (US\$ thousands) }\end{array}$ \\
\hline \multicolumn{6}{|c|}{ Panel A: Global natural disasters } \\
\hline Climatological & 1461 & $11,881,372$ & $2,258,591,701$ & $198,489,104$ & 135,858 \\
\hline Hydrological & 4729 & $6,992,618$ & $3,534,240,607$ & $593,558,557$ & 1479 \\
\hline Meteorological & 7149 & $2,766,859$ & $1,850,620,901$ & $1,872,273,246$ & 387 \\
\hline \multicolumn{6}{|c|}{ Panel B: Climatological disasters } \\
\hline Drought & 630 & $11,707,611$ & $2,155,147,897$ & $88,674,906$ & 140,978 \\
\hline Extreme temperature: Cold wave & 256 & 15,493 & $12,304,064$ & $12,177,284$ & 47,568 \\
\hline Extreme winter conditions & 51 & 3,460 & $80,542,897$ & $22,940,000$ & - \\
\hline Extreme temperature: Heat wave & 159 & 151,186 & $4,653,436$ & $22,389,859$ & 140,817 \\
\hline Wildfire: Unspecified & 9 & 132 & 60,884 & $2,016,000$ & 224,000 \\
\hline Bush/Brush fire & 7 & 277 & 20,295 & $3,767,000$ & 538,143 \\
\hline Forest fire & 252 & 2,662 & $5,047,527$ & $41,917,761$ & 166,340 \\
\hline Scrub/grassland fire & 97 & 551 & 814,701 & $4,606,294$ & 47,488 \\
\hline Sub-Total & 1461 & 1,881,372 & 2,258,591,701 & $198,489,104$ & 135,858 \\
\hline \multicolumn{6}{|c|}{ Panel C: Hydrological disasters } \\
\hline Flood: Unspecified & 1,286 & $2,432,686$ & $910,493,253$ & $89,788,882$ & 69,820 \\
\hline Flash flood & 494 & 63,685 & $171,008,701$ & $49,677,236$ & 100,561 \\
\hline General flood & 2258 & $4,431,010$ & $2,417,905,474$ & $435,319,465$ & 192,790 \\
\hline General flood/Mudslide & 1 & 11 & 9950 & - & - \\
\hline Storm surge/coastal flood & 81 & 5341 & $21,125,409$ & $10,322,976$ & 127,444 \\
\hline Mass movement wet: Avalanche & 86 & 4051 & 71,146 & 824,889 & 9592 \\
\hline Mass movement wet: Landslide & 520 & 55,408 & $13,623,836$ & $7,625,109$ & 14,664 \\
\hline Mass movement wet: Rockfall & 1 & 33 & - & - & - \\
\hline Debris flow & 1 & 106 & - & - & - \\
\hline Subsidence & 1 & 287 & 2838 & - & - \\
\hline Sub-Total & 4729 & $6,992,618$ & $3,534,240,607$ & $593,558,557$ & 125,515 \\
\hline \multicolumn{6}{|c|}{ Panel D: Meteological disasters } \\
\hline Storm: Unspecified & 1658 & 60,860 & $125,963,460$ & $144,558,786$ & 87,189 \\
\hline Extratropical cyclone & 96 & 482 & $6,809,210$ & $62,053,978$ & 646,396 \\
\hline Extratropical cyclone (winter storm) & 64 & 360 & $1,010,750$ & $38,914,300$ & 608,036 \\
\hline Local storm & 1459 & 36,273 & $383,485,463$ & $321,944,840$ & 220,661 \\
\hline Tropical cyclone & 3872 & $2,668,884$ & $1,333,352,018$ & $1,304,801,342$ & 336,984 \\
\hline Sub-Total & 7149 & $2,766,859$ & $1,850,620,901$ & $1,872,273,246$ & 261,893 \\
\hline
\end{tabular}

Source: CRED EM-DAT database. 
According to Munich Re, the global insurance company, more than 950 natural disasters (90\% of total disasters) was weather related disasters in 2010, costing a total of at least $\$ 130$ billion. Insured losses also increase as overall losses of weather catastrophes but the level of increases of insured losses is less compared with overall losses. In 2012, overall and insured losses are around $\$ 149.6$ billion and $\$ 67.9$ billion respectively because of meteorological, hydrological, and climatological disasters. Moreover, according to the data obtained from $\mathrm{Mu}-$ nich Re, highly insured countries which the property insurance premium is larger than $\$ 1000$ per capita (e.g., North America, Australia, and North Europe) have largest percentage of overall losses at around $47 \%$ and natural catastrophes at 37\% between 1980 and 2009. However, 54\% of fatalities is contributed by inadequately insured countries which the property insurance premium is less than $\$ 10$ per capita (e.g., mainly in Southern Asia and East Africa). On the other hand, according to Munich Re., the overall losses have been $\$ 1600$ billion and the insurance penetration for natural catastrophe is only $14 \%$ in Asia. All of these shows that an increase in climate-related extreme weather events potentially manifest the fact that governments have to pay much attention to disaster risk management (Linnerooth-Bayer and Mechler, 2006) [1].

\section{Climate Change Adaptation and Economic Theory}

Only a few of previous literature applies Laissez faire theory, public interest theory, and market enhancement theory to discuss climate change adaptation and the financial support mechanisms.

Laissez faire theory suggests that market efficiency is achieved by balancing production and demand of goods and is also improved when government reduce the intervention. Though the most industrial countries are referred to laissez faire economies, the laissez faire theory is not completely implemented. Groups (e.g. government and public) have difference in awareness about climate change adaptation; therefore, climate change adaptation should be distinguished between groups when lasses faire theory is applied to climate change adaptation.

In contrast, Public interest theory suggests that governments enhance economic efficiency by specific regulation since this theory proposes that unrestricted competition reduces the economic efficiency (Dannenberga et al., 2009) [6]. Government intervention also promotes the social welfare when externality and market failure exist. Dannenberga et al. (2009) [6] suggest that policies of climate change adaption result in redistribution and promote the governments to adjust social policies.

Market enhancement theory suggests that governments aim at market enhancement through regulations and laws, such as enhancing market transaction, promoting market development, and sustaining market order. It is often applied to discuss climate change adaption in related literature. Unlike laissez fair theory and public interest theory that are not completely applied to explain economic activities, market enhancement theory seems to balance the advantages of laissez faire theory and public interest theory. Governments do not intervene in markets but they use regulations to promote market development. Previous literature concludes that market enhancement theory is applied in climate change adaptation that market mechanisms promote public to response for climate changes.

In general, financial instruments are usually emphasized by public interest theory and market enhancement theory (Dannenberga et al., 2009) [6] since market failure always occur in the short-term after disaster.

\section{Financial Instruments and the Cases}

Large economic losses from natural disasters have been having a heavy burden of societies and governments. Governments must be responsibility for reconstructing the infrastructure after disasters. They are generally financing using various sources, such as financing by taxes, budget reallocation, domestic or international credit loans, and borrowing from multilateral financial institutions. However, economic development projects possibly release if the budgets of infrastructure are used for relieving distress and reconstructing. In addition, private investment is very important for the long-term reconstruction and national sustainable development but adding tax may decrease new private investments.

Michel-Kerijan et al. (2011) [2], as described in Figure 1, suggest four-level approach chosen by a government based on its priorities and level of economic development. Level 1 is for the very limited funding from central government (i.e., low-income economies). Since financing instruments against natural disaster is often absent in most low-income economies, post-disaster funding from international donorsis the main financing resources in low-income countries, such as the IMF, World Bank, Asian Development Bank, and private charities. They often have to wait for funding for several months. Moreover, the level of donations may be significantly 


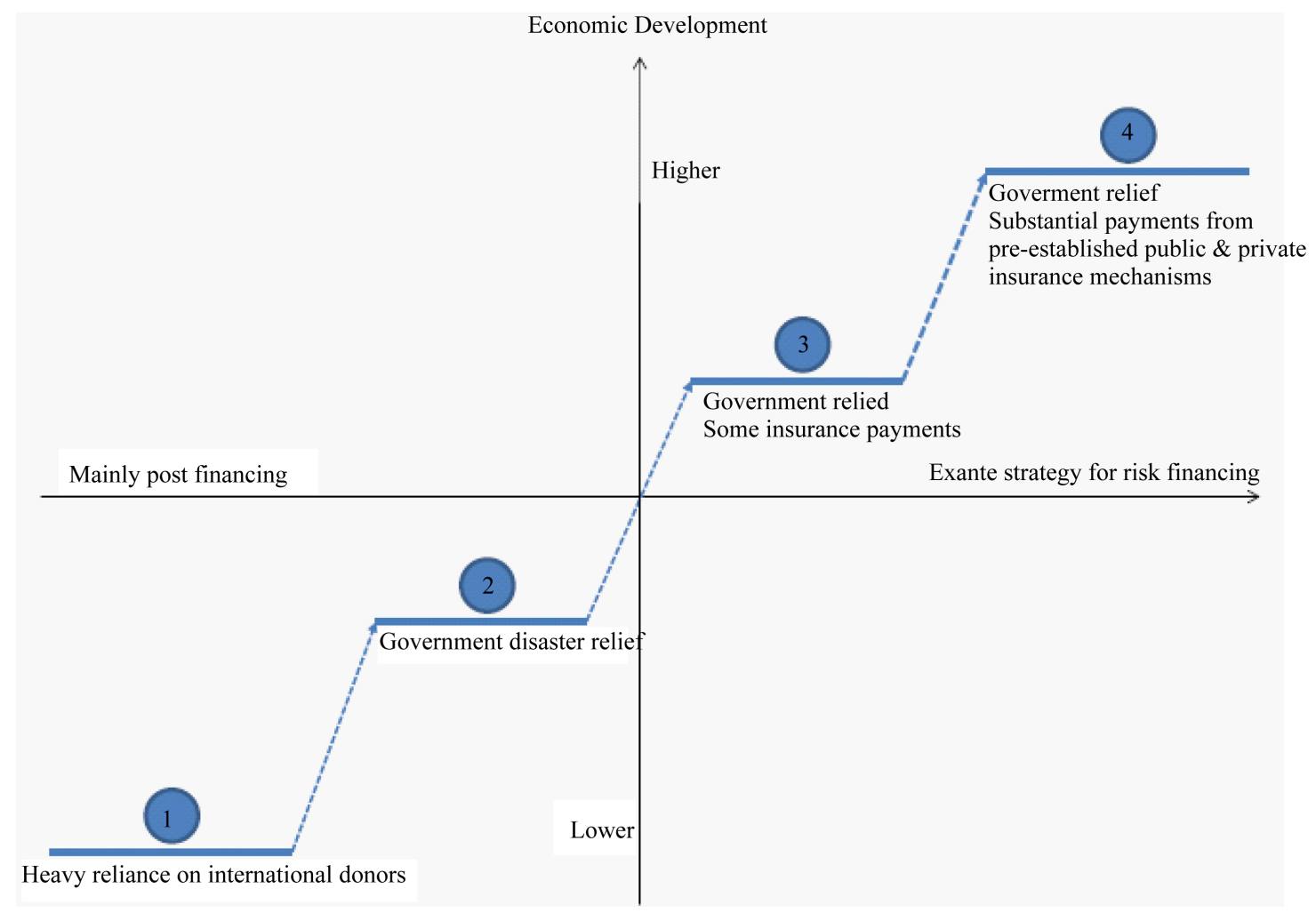

Figure 1. Government responses to disaster financing depending on its priorities and level of economic development. Source: Michel-Kerijan et al. (2011).

lower after a series of other large-scale disasters. If only relying on international donors, it is a very uncertain strategy for countries. In Level 2, ex-post funding is mainly from the central government. The central government raises the level of revenues through taxes increases thus post-disaster funding from the central government is faster relief compared with Level 1 countries. Michel-Kerijan et al. (2011) [2] think that the level of technical expertise in risk management in these countries is usually higher but still limited. In Level 3, as the level of economic development improvement, ex-post funding is mainly from the central government but there is some coverage by insurance systems. At this level, public insurance, private insurance, and micro-insurance are present but private insurance penetration is still low. The level of technical expertise in risk management in these countries is also often higher than in Level 2. However, the disaster coverage solutions developed in these countries is often quite basic and the private markets do not have the both capital base and expertise to insure concentrated portfolios of risks. In Level 4, often in rich countries and highly economic development countries, significantly high insurance and reinsurance penetration are against natural disaster and government supplements by allocating catastrophic risk capital. Governments still play important roles in providing some types of insurance (reinsurance) for truly catastrophe risks. The risks are generally covered by both public and private sector. Actually, many rich countries (e.g., the United States, Japan, Germany, France and the UK) have developed catastrophe financing solutions based on public-private partnership which the insurer provides insurance coverage for a given type of catastrophe and governments agree to take steps to mitigate that risk across the country.

Figure 2 suggested by Ghesquiere and Mahul (2010) [3] shows the instruments used by governments after the disasters and it also provides an assessment of the time necessary financing using these instruments. The ex-post instruments have to take some time to mobilize. In contrast, the advantage of ex-ante instruments is allowed for quick expenditure since this instrument is secured before disaster.

Ghesquiere and Mahul (2010) [3] suggest that different types of financing instruments have to be used in different phase after disaster. They think that funding used in recovery phase and reconstruction phase will not be required immediately following a disaster while relief operations require immediate resources following a disaster. Ghesquiere and Mahul (2010) [3] suggest the design of an efficient financial protection strategy must con- 


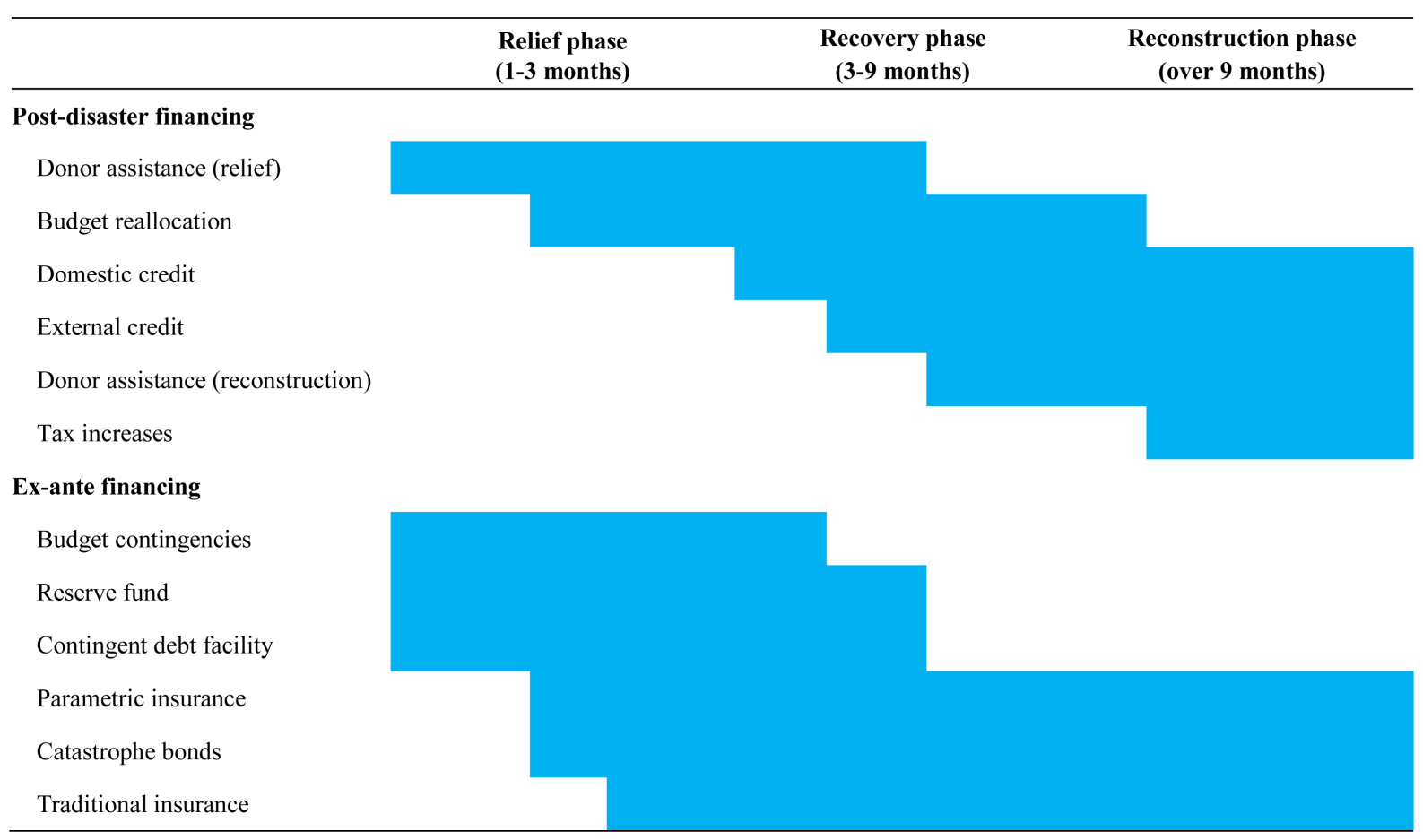

Figure 2. Sources of post-disaster financing. Source: Ghesquiereand Mahul (2010).

sider the time dimension for financial instruments to ensure that funding requirements are synchronized with the capacity.

Actually, governments would consider both level of economic development (Michel-Kerijan et al., 2011) [2] and time dimension (Ghesquiere and Mahul, 2010) [3] to design a financial protection strategy. In generally, there is more than one financial instrument used in order to match funding requirements when require. For example, in Japan, government budgets against disasters are approximately $5 \%$ of the general fund in the national budgets. Besides, insurers and reinsurers in Japan are allowed to establish reserves for future catastrophes. Public-private partnership (e.g., Japan Earthquake Reinsurance) is also present in Japan. Another example in Mexico, to respond exposure risk from earthquakes and hurricanes, the Government of Mexico has been active in developing a public policy strategy on risk management since the mid 1990s. Nowadays, a special allocation in the federal budget as natural disaster funds called the Fonden was established in 1996 and a catastrophe bond called GFDRR was also issued in 2006.

The principal aim for governments are that complete reconstruction using plenty of reconstruction funds but this probability leads to the heavy burden on government finance. Four disaster risk financing instruments are generally used by governments, including government bonds, tax-deductible reserve, and insurance related financial instruments. Besides, index-linked insurance, insurance-linked securities (ILS) are contained by the insurance related financial instruments, and public-private partnership (PPP). This section will introduce the general financial instruments mentioned above when governments have to finance funds to reconstruction. Actual cases of these financial instruments are also introduced and analyzed.

\subsection{Government Bonds}

Government bonds or state bonds are a major and feasible financing source without adding tax when governments do not have enough finance to reconstruct. Government bonds are a main financial instrument and ex-post funding in Level 2 countries (Michel-Kerijan et al., 2011) [2]. They are often used for infrastructure rehabilitation and reconstruction in recovery phase and reconstruction phase (Ghesquiere and Mahul, 2010) [3]. Moreover, donor assistance is often accompanied by government bonds in many developing countries. However, with an increase on debt-to-GDP ratio, the special budget for post-disaster fund reconstruction financed from government bonds or state bonds make deterioration of government finances if a country suffers from the huge disas- 
ters. Moreover, high debt-to-GDP ratio will be detrimental to a country's economic development in the long-run. Therefore, both government bonds as ex-post funding and insurance as ex-ante funding are against losses from natural disaster in Level 3 and Level 4 countries.

\subsection{Tax-Deductible Reserves}

Insurance companies are permitted or required to set reserves for future payment of claims from disasters in many industrial countries. For example, in the past, insurer did not be allowed to establish reserves for future catastrophes in the United States. After Hurricane Andrew in 1992, the US Congress entertained the proposals that insurers and reinsurers are allowed to establish tax-deferred loss reserves which could only assess in the case of a catastrophe. The proposals have been discussed again after the most recent severe hurricane seasons (Davidson, 1996) [7]. As at present, however, the proposal developed by NAIC is still not formally legislated, many countries have permit insurers to set reserves for future catastrophic risk. Tax-deductible reserves are one of ex-ante financial instrument in Level 3 and Level 4 countries (Michel-Kerijan et al., 2011) [2], and reserve fund which is used for payments of claimsin relief phase and in several months of recovery phase after natural disaster (Ghesquiere and Mahul, 2010) [3].

\subsection{Insurance Related Financial Instruments-Index-Linked Insurance, Insurance-Linked Securities, and Public-Private Partnership}

Insurance related financial instruments are ex-ante funding and are often used in developed countries, such as Level 4 countries (Michel-Kerijan et al., 2011) [2]. Unlike traditional insurance in Level 3 countries, parametric insurance covers from relief phase to reconstruction phase after disasters based on the insurance types and objects (Ghesquiere and Mahul, 2010 [3]; Michel-Kerijan et al., 2011 [2]). In the decade, some insurance related financial instruments are often used in industrial countries, including index-linked insurance, insurance-linked securities, and public-private partnership. Insurance-linked security is the second insurance related financial instrument. Catastrophe risk transferred to the capital market is common and rapidly developed worldwide. Many governments control risk of different kinds of natural disasters through securitization (e.g., the United States, Europe, Japan, Australia, Mexico, and Turkey). Catastrophe bond is the best-known and risk-linked securities. It associates insurance markets with capital markets and then transfers specific disaster risks to investors. The investors will receive a return which is higher than market return when a specific catastrophe does not occur in a specific time.

The final insurance related financial instrument is public-private partnership (hereafter called PPP). It is a government service or private business venture which is a partnership of public sector authorities (government) and one or more private sector companies (insurance industry). Most PPPs were negotiated individually and began in 1990s. In 1992, the first systematic programme, the private finance initiative (PFI), was introduced in the United Kingdom and aims at decreases in the public sector borrowing requirement.

The scope of responsibility to financial risks diversified of government is defined by public sector authorities and private sector companies according to the type of disaster risk, the degree of covering disaster, and extent of disaster effect. For example, disaster insurance funds are established to diversify government fiscal risk. According to the experience of many countries, governments pay only $30 \%$ to $70 \%$ of losses after disaster if insurance system performs well. PPPs are funded and operated by insured, insurance companies, international reinsurers, and government. Policy of insured and claimed is operated by insurance companies; disaster risk is undertaken by both public sector authorities and private sector companies; reserve emergency funds and financial guarantee is provided by governments (Figure 3 ).

Insurance related financial instruments are one type of parametric insurance and ex-ante strategy for risk financing according to the suggestion by Ghesquiere and Mahul (2010) [3]. They are also probably used in Level 4 countries in Michel-Kerijan et al. (2011) [2]. However, the World Bank and other international associations help some governments to pilot insurance related financial instruments especially in middle-income countries after year 2000 .

\subsection{The Cases}

Table 2 shows the cases of financial mechanismin climate adaptation around the world. It documents that de- 
Table 2. International cases about climate change financial mechanism.

\begin{tabular}{|c|c|c|c|c|}
\hline Cases & Risks/Index & Financial mechanism & Target users & Year \\
\hline \multicolumn{5}{|c|}{ Panel A: National disaster relief and government bonds } \\
\hline China (Heilongjiang) & Drought/rainfall & National disaster relief & farmers & - \\
\hline India & Drought, excessive rainfall/rainfall & National disaster relief & $\begin{array}{l}\text { farmers (big, mid, small } \\
\text { scale) }\end{array}$ & 2004 \\
\hline Mexico & Drought, flood/rainfall & National disaster relief & $\begin{array}{l}\text { State governments, } \\
\text { tenant-farmers }\end{array}$ & 2002 \\
\hline Samoa & sealevels rise/sea level & National disaster relief & residents & - \\
\hline Thailand & Drought/rainfall & National disaster relief & corn tenant farmers & 2007 \\
\hline Ukraine & Drought/rainfall & National disaster relief & $\begin{array}{l}\text { food crops and tenant } \\
\text { farmers }\end{array}$ & 2005 \\
\hline United States (Florida) & Hurricane/wind speed, rainfall & Government bonds, PPP, ILS & residents & - \\
\hline \multicolumn{5}{|c|}{ Panel B: Index-insurance } \\
\hline Brazil & Drought/area yield & Support farmers' seed programs & corn farmers & 2001 \\
\hline Caribbean & $\begin{array}{l}\text { Hurricane, Earthquake/wind speed } \\
\text { and seismic intensity scale }\end{array}$ & Catastrophe risk insurance & $\begin{array}{l}\text { The governments of } \\
\text { Caribbean }\end{array}$ & 2007 \\
\hline Ethiopia & Drought/rainfall & Natural disaster insurance & $\begin{array}{l}\text { United Nations World Food } \\
\text { Programme (WFP) }\end{array}$ & 2006 \\
\hline Ethiopia & Drought/rainfall & Insurance in rural areas & corn tenant farmers & 2006 \\
\hline Ethiopia (Adi Ha) & Drought/rainfall & farmers & straw farmers & - \\
\hline India & $\begin{array}{c}\text { Potato crop failure/temperature and } \\
\text { humidity }\end{array}$ & Agricultural insurance contracts & potato farmers & 2007 \\
\hline India & $\begin{array}{l}\text { Flood, drought, extreme } \\
\text { temperatures, natural disaster, fog, } \\
\text { and humidity/temperatures, rainfall }\end{array}$ & Simple weather index insurance & $\begin{array}{l}\text { farmers (big, mid, small } \\
\text { scale) }\end{array}$ & 2003 \\
\hline Malawi & Drought/rainfall & Index-based insurance & groundnut farmers & - \\
\hline Middle America & $\begin{array}{l}\text { Drought and excessive } \\
\text { rainfall/rainfall }\end{array}$ & Index insurance & peanut and rice farmers & 2007 \\
\hline Mongolia & $\begin{array}{l}\text { Large animals died in the harsh } \\
\text { climate/regional livestock mortality } \\
\text { rate }\end{array}$ & Livestock insurance & nomads & 2006 \\
\hline Turkey & earthquake & Catastrophe Insurance Pool & residents & 2000 \\
\hline $\begin{array}{l}\text { Vietnam (Mekong } \\
\text { Delta) }\end{array}$ & $\begin{array}{l}\text { Flood advance submerged } \\
\text { paddy/river rating }\end{array}$ & Flood insurance & $\begin{array}{l}\text { National Agricultural Bank } \\
\text { (NAB) }\end{array}$ & - \\
\hline \multicolumn{5}{|l|}{ Panel C: ILS and PPP } \\
\hline Mexico & Earthquake, hurricane & Catastrophe bond & residents & 2006 \\
\hline United Kingdom (Hull) & $\begin{array}{l}\text { Flood, snowstorm, sealevels } \\
\text { rise/rainfall }\end{array}$ & PPP, ILS & residents & - \\
\hline United States (Florida) & Hurricane/wind speed, rainfall & Government bonds, PPP, ILS & residents & - \\
\hline \multicolumn{5}{|c|}{ Panel D: Disclosure system } \\
\hline Malawi & Drought/rainfall & Disclosure of potential & tobacco farmers & 2005 \\
\hline Malawi & $\begin{array}{l}\text { Drought/rainfall (relative with the } \\
\text { production of corn) }\end{array}$ & $\begin{array}{c}\text { National system for drought risk } \\
\text { management }\end{array}$ & Malawi Government & 2008 \\
\hline
\end{tabular}

Source: Linnerooth-Bayer and Mechler (2006), UNEP, World Food Program, International Research Institute for Climate and Society etc. 


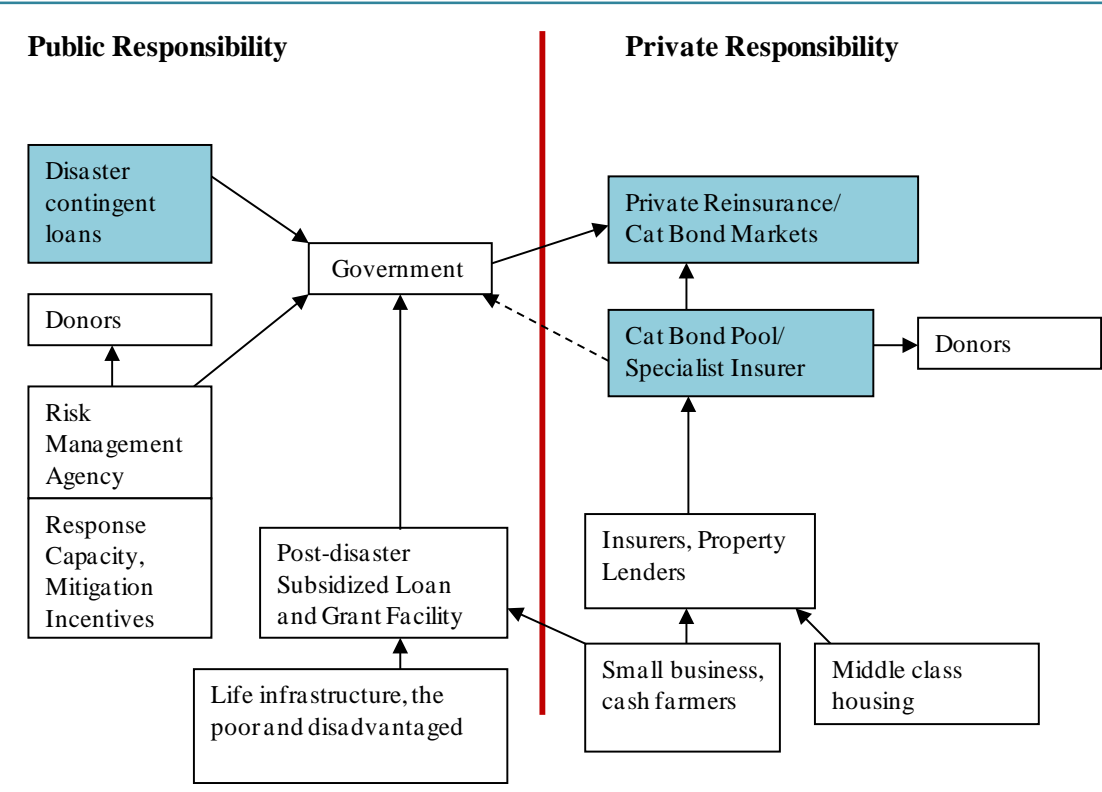

Figure 3. The structure of Public-Private Partnerships. Source: Global Facility for Disaster Reduction and Recovery (GFDRR).

veloped countries both use government bonds and insurance related financial instruments to protect against the damage caused by the extreme weather. For developing countries, the insurance related financial instruments may be made feasible in the initial stages with technical assistance from the World Bank or other international association.

\section{Example: Japanese government budgets}

Besides earthquake insurance for household, the Japanese government budgets against from disaster,is approximately $5 \%$ of the general fund in the national budget. The government budget is at $¥ 4.5$ trillion ( $\$ 49.9$ billion) each year on average for disaster management from 1995 to 2004. Phaup and Kirschner (2010) [8] document that the budget for disaster management is separated into four fields, including scientific technology research (1.3\%), disaster prevention and preparedness (23.6\%), national land conservation (48.7\%), and disaster recovery and rehabilitation (26.4\%).

\section{Example: Agricultural and index-based insurance schemes-Index-bases insurance in Malawi}

More than $40 \%$ farmers in developing countries face the threats of harm on their livelihoods and grain caused by extreme weather (World Bank, 2005) [9]. The agriculture sector has a long experience with adaptation to changes on environment condition because farmers have experimented with their crops and cultivation methods to adapt optimally to their respective climate regimes (Dannenberg et al., 2009) [6]. However, according to the World Food Programme (2005, p. 7) [10]: "Because of the extreme and covariant nature of the risks they face, and in the absence of risk-management instruments such as crop insurance, risk-averse smallholder farmers naturally seek to minimize their exposure... These risk-management choices also keep farmers from taking advantage of profitable opportunities; they are a fundamental cause of continued poverty." Linnerooth-Bayer and Mechler (2006) [1] suggest that affordable insurance not only provides low-income farm households with postdisaster liquidity but also protects their livelihoods. Moreover, insurance improves small farmers' credit worthiness and promotes them to engage in higher-return crop practices.

Agricultural and index-based insurance scheme mitigate the impacts of climate extremes on rural population (Hoff et al., 2005 [11]; Linnerooth-Bayer and Mechler, 2006). The World Bank and World Food Programme helped start a Malawi pilot weather insurance project. The weather insurance project in Malawi is a parametric insurance of ex-ante strategy for risk financing in Level 4 (Ghesquiere and Mahul, 2010 [3]; Michel-Kerijan et al., 2011 [2]). The Malawi government pilot project organized by the National Smallholder Farmers Association provides a packaged loan and index-based micro-insurance to groundnut farmers. A loan agreement with a higher interest rate includes the weather insurance premium which the bank and rural finance institution pay to the insurer (the Insurance Association of Malawi). However, the credit was 33\% for farmers offered by loan 
without insurance and only $17.6 \%$ for farmers offered by loan bundled with rainfall insurance. Actually, Giné (2009) [12] finds that the ratio of expected payouts on rainfall index insurance compared with premium was estimated at only approximately 30\% on average. After the pilot, lenders decide to bundle all agricultural loans with insurance. It is cloudy that borrowers remain largely unaware loans insured although insurance may have increased access to credit.

\section{Example: Assisting insurance-linked securities-Mexico's catastrophe bond}

Mexico's natural disaster fund has been financed the post-disaster reconstruction fund through market financing mechanism in the past ten years. In 2006, Mexico became the first sovereign country to issue a catastrophe bond with technical assistance from the World Bank. In October 2009, Mexico issued a catastrophe bond at $\$ 290$ million, which mature in October 2012, cover catastrophes occurring after October 15 . It is a three-year insurance which includes \$140 million in earthquake damage protection, \$100 million against Pacific hurricanes (two areas) and \$50 million against Atlantic hurricane. Ivan Zelenko, head of derivatives and structured finance at the World Bank Treasury, said that "If more investors come, there is more risk-taking capacity that is going to bring down the premium,” which benefits the issuing countries (Bloomberg, 2009) [13].

Although Mexico is not a very rich country as Level 4 country in Michel-Kerijan et al. (2011) [2], the Mexico government with assistance from the World Bank issued a catastrophe bond (Ghesquiere and Mahul, 2010) [3]. Linnerooth-Bayer and Mechler (2006) [1] suggests that Mexico’s catastrophe bond is feasible and successful since Mexico is a middle-income country and a member of the OECD. This similar case probably fails in lowincome countries and just represents another opportunity for assistance from a climate insurance programme for low-income countries. Finally, Mexico's case also takes advantage of other financial instruments. For example, in 2005, the World Bank has agreed to support the Colombian government's risk management plan with a contingent credit arrangement (Linnerooth-Bayer and Mechler, 2006 [1]). The case in Mexico, catastrophe bonds which is an ex-ante strategy for disaster risk financing in Level 4 countries (Ghesquiere and Mahul, 2010 [3]; Michel-Kerijan et al., 2011 [2]) are feasible in middle-income countries if governments with assistance from international associations, such as the World Bank and the World Food Programme [10].

\section{Example: Public-Private Partnerships in United States}

In general, the private sector is seen as a better manager of financial risk while governments are seen as a better manager of regulatory risk (Sharp and Tinsley, 2005) [14]. One of the most successful mitigation efforts is Federal Emergency Management Agency (FEMA) which continues to be a catalyst and model for public-private partnership efforts worldwide.

In August, 2005, Hurricane Katrina caused deaths and flooding, and its damage was around \$125 billion with $\$ 62$ billion in insured losses. Thus, a programme operated as a public-private partnership, collecting more than $\$ 2$ billion in annual premiums. The programme was managed by the FEMA and all risks were faced by governments.

In summary, developed countries both use government bonds and insurance related financial instruments to protect against the damage caused by the extreme weather. Since 1992, the first systematic programme was introduced in the United Kingdom and thus developed countries have experience about PPP for a long time. According to the actual cases of many developed countries in the past, governments pay only $30 \%$ to $70 \%$ of losses after disaster if insurance system performs well. These cases are consistent with Michel-Kerjan et al. (2011) [2] that rich countries use insurance products against catastrophe risks and design efficient financial protection strategy. On the other hand, most of developing countries still use government fiscal budget or government to pay the losses from natural disaster. This is also consistent with Michel-Kerjan et al. (2011) [2]. Furthermore, insurance penetration is limited and people may not afford to pay for insurance coverage obtained through insurance markets or a national public insurance program in low- and middle-income countries. Fortunately, insurance-related instruments have been gradually accepted and exercised by developing countries with technical assistance from the World Bank. This kind of financial mechanisms is feasible for middle-income countries through the World Bank programme but this may be difficult to be exercised for low-income countries.

\section{Conclusions}

Extreme weather has been an increase in frequency and severity because of global warming. It is expected that heavy financial burden on governments is increasing caused by reconstruction of huge enormous natural disaster and prevention of public construction spending. This study aims at introducing financial support mechanisms 
and analyzing the cases in the past years. We collect cases in both developed and developing countries and then focus on several financial support mechanisms used frequently by governments at present, including state bonds, tax-deductible reserves, Public-Private Partnership, and insurance-linked securities. We also discuss these financial support mechanisms according to Ghesquiere and Mahul (2010) [3] and Michel-Kerijan et al. (2011) [2].

We find that fiscal budget reallocation or government bonds are regularly used to pay the losses from natural disaster in many developing countries. Moreover, insurance penetration is actually limited and people probably afford to pay for insurance coverage obtained through insurance markets or a national public insurance program in low- and middle-income countries. These cases are consistent with Michel-Kerjan et al. (2011) [2] that rich countries use insurance products against catastrophe risks and design efficient financial protection strategy while low- and middle-income countries often use government fiscal budget or government as financial instruments. In order to promote insurance penetration, insurance-related instruments have been gradually accepted and exercised in some developing countries with technical assistance from the World Bank. This kind of financial mechanisms is feasible for middle-income countries with assistance from the World Bank programme but this is difficultly exercised in low-income countries at present, especially in very low-income countries. We therefore expect more studies to devote in this field in the future.

\section{References}

[1] Linnerooth-Bayer, J. and Mechler, R. (2006) Insurance for Assisting Adaptation to Climate Change in Developing Countries: A Proposed Strategy. Climate Policy, 6, 621-636. http://dx.doi.org/10.1080/14693062.2006.9685628

[2] Michel-Kerjan, E., Zelenko, I., Cardenas, V. and Turgel, D. (2011) Catastrophe Financing for Governments: Learning from the 2009-2012 MultiCatProgram in Mexico. OECD Working Papers on Finance, Insurance and Private Pensions 9, OECD Publishing. http://dx.doi.org/10.1787/5kgcjf7wkvhb-en

[3] Ghesquiere, F. and Mahul, O. (2010) Financial Protection of the State against Natural Disasters: A Primer. World Bank Policy Research Working Paper 5429.

[4] CRED EM-DAT Database. http://www.emdat.be/

[5] UNEP (2008) Adaptation and Vulnerability to Climate Change: The Role of the Finance Sector. UNEP Finance Initiative.

[6] Dannenberga, A., Mennela, T., Osberghausa, D. and Sturm, B. (2009) The Economics of Adaptation to Climate Change-The Case of Germany. Centre for European Economic Research, Discussion Paper No. 09-057.

[7] Davidson Jr., R.J. (1996) Tax-Deductible Prevent Catastrophe Reserve. Journal of Insurance Regulation, 15, $175-190$.

[8] Phaup, M. and Kirschner, C. (2010) Budgeting for Disasters: Focusing on the Good Times. OECD Journal on Budgeting, 10, 1-24. http://dx.doi.org/10.1787/budget-10-5kmh5h6tzrns

[9] World Bank (2005) Commodity and Weather Risk Management Programs to be Expanded. World Bank News and Broadcast.

[10] World Food Programme (2005) Pilot Development Project: Ethiopia Drought Insurance 10486.0. Project for Executive Board Approval, WFP/E.B.2/2005/8-A, Rome.

[11] Hoff, H., Warner, K. and Bouwer, L.M. (2005) The Role of Financial Services in Climate Adaptation in Developing Countries. Vierteljahrshefte zur Wirtschaftsforschung, 74, 196-207. http://dx.doi.org/10.3790/vjh.74.2.196

[12] Giné, X. (2009) Innovations on Insuring the Poor: Experience with Weather Index-based Insurance in India and Malawi. International Food Policy Research Institute, 2020 Focus 17 Brief 7.

[13] Bloomberg (2009) Mexico Issues Catastrophe Bonds through World Bank (Update1), Jamie McGee and Carlos Manuel Rodriguez.

[14] Sharp, L. and Tinsley, F. (2005) PPP Policies throughout Australia: A Comparative Analysis of Public Private Partnerships. Public Infrastructure Bulletinl, 21-34. 